\title{
Towards a Multisourcing Maturity Model as an Instrument of IT Governance at a Multinational Enterprise
}

\author{
Thomas Ph. Herz \\ University of St.Gallen \\ thomas.herz@unisg.ch
}

\author{
Florian Hamel \\ University of St.Gallen \\ florian.hamel@,unisg.ch
}

\author{
Falk Uebernickel \\ University of St.Gallen \\ falk.uebernickel@unisg.ch
}

\author{
Walter Brenner \\ University of St.Gallen \\ walter.brenner@unisg.ch
}

\begin{abstract}
Many multinational enterprises are applying multisourcing approaches. Multisourcing is described as the blending of services from multiple internal and external vendors. In the case of one of the worldwide leading financial service providers the implementation of the multisourcing concept at the numerous business entities has been challenging since the group follows a federal IT organization model. By applying action research a multisourcing maturity model has been developed as an IT governance instrument. It is inspired by established maturity models and adapts proven methodologies whilst targeting the specific requirements of multisourcing. Thereby the maturity model provides transparency across all business entities, enables continuous monitoring of the multisourcing implementation progress and allows the provisioning of best-practices to a corporate group. With this article the authors provide insights into a real-life example of developing and implementing a multisourcing strategy and suggest an IT governance instrument for a multinational enterprise.
\end{abstract}

\section{Introduction}

Information Technology (IT) outsourcing has, over the last two decades, been widely discussed and investigated by scientific scholars. The worldwide IT outsourcing market was estimated at 114.6 billion USD in 2009 and - with a Compound Annual Growth Rate (CAGR) of three percent - is anticipated to reach 131.3 billion USD in 2013 [28].

In recent times it can be observed that mega-deals under a sole-sourcing approach are less frequent and companies have moved to a more selective outsourcing approach applying multisourcing strategies. The sourcing advisory firm TPI found that whilst outsourcing deals with a volume greater than one billion USD - so called mega-deals - have decreased both in size and prevalence during the last years, the number of outsourcing deals singed have increased $[13,20]$.

Both scholarly as well as practitioner-related literature has identified multisourcing as an emerging key strategy in today's IT outsourcing endeavors [18, $8,17,22]$. Multisourcing is defined as the blending of services from multiple internal and external vendors [8]. The main drivers for applying multisourcing strategies are companies' increased need for cost efficiency, flexibility, and quality in a dynamic and global business environment [18].

A leading financial company - in the following called company ALPHA - also developed a multisourcing strategy and encountered a number of challenges with the implementation at its more than 100 business entities. In particular, the group's federal IT organization and low central governance require group-wide transparency, continuous monitoring of the implementation progress and the provisioning of bestpractices to all business entities in order to make the multisourcing strategy work. Therefore the need for a new, multisourcing specific IT governance instrument was identified and company ALPHA decided to introduce a maturity model specifically dedicated to multisourcing. In order to contribute both to the practical concerns of company ALPHA and the scientific body of knowledge an action research based approach has been chosen. With this article the authors present the approach accomplished and target the following two research questions (RQ):

\section{[RQ.1] Are existing best-practices and especially established maturity models applicable to a multisourcing specific situation at a multinational enterprise with a federal IT organization? \\ [RQ.2] What could a multisourcing specific maturity model targeting the challenges of a multinational enterprise with a federal IT organization look like?}

The paper is structured as follows: First, the research approach chosen will be described. Second, 
the authors give an overview about company ALPHA, its journey towards multisourcing, and the identification of company ALPHA's specific multisourcing requirements. Third, the authors present the analysis of existing maturity models and illustrate the development of a multisourcing specific approach. Finally, the authors point out the lessons learned and describe next steps and future challenges.

\section{Research approach}

In order to target company ALPHA's specific challenges and contribute concurrently to the scientific body of knowledge an action research based approach was chosen. The overall aim of action research is to solve practical problems and promote scientific progress at the same time $[14,23,7,19]$. Action research thereby provides exceedingly relevant research findings [3]. It merges research with praxis. This can be illustrated as follows: On the one hand it was important to company ALPHA to develop an IT governance instrument that facilitates the degree of implementation of the multisourcing strategy across the group in order to achieve group-wide objectives (see 3.2). On the other hand a literature review has indicated that the body of knowledge lacks depth in terms of multisourcing governance [12].

Action research "first requires the establishment of a client-system infrastructure or research environment" [3]. This is represented by one of the authors being part of the team at company ALPHA that was in charge of developing the multisourcing specific IT governance instrument. According to Baskerville [2] the most prevalent approach of action research applies a five phase, cyclical process encompassing diagnosing, action planning, action taking, evaluating, and specifying learning $[2,27]$.

The researcher's contribution encompassed the setup and coordination of the project plan, identification of company ALPHAs requirements, review of literature, analysis of existing best-practices, development of the maturity model concept, plan and execution of development and evaluation workshops, accomplishment of interviews and documentation. All steps were accomplished in a collaborative way and all relevant stakeholders - the central multisourcing team at ALPHA and the representatives of the business entities at ALPHA, the own offshore centre as well as the strategic external vendors - have been involved continuously. The principles of canonical action research were met [10]:

Agreement between researcher and client: Before the project started the researcher and company ALPHA agreed on the development of an IT governance instrument that fertilizes the implementation of the multisourcing strategy. The researcher and company ALPHA agreed on the timetable, the objectives and the roles and responsibilities.

- Iterative process model: Table 1 illustrates the iterative process model that has been applied in the project. It shows a three-step development of the maturity model and the involved stakeholders.

- Theoretical foundation: A literature review ascertained the need for further research in terms of multisourcing governance [12]. In addition, the first version ( $\mathrm{v} \_$) of the maturity model was based on established models identified in the literature.

- Principal of change: The willingness to bring about change was identifiable throughout the project and fully supported by representatives of company ALPHA.

- Learning through reflection: A rigorous documentation of the concept, accompanying information as well as the lessons learned, was accomplished. Reflections on outcomes were integrated into each following iterative cycle.

Table I: Iterative process model

\begin{tabular}{|l|l|l|l|}
\hline $\begin{array}{l}\text { Maturity } \\
\text { model } \\
\text { version }\end{array}$ & $\begin{array}{l}\text { Iter- } \\
\text { ative } \\
\text { cycle }\end{array}$ & Stakeholder & Position \\
\hline $\begin{array}{l}\text { v_0 } \\
\text { (based on } \\
\text { literature) }\end{array}$ & N/A & N/A & N/A \\
\hline v_1 & I & $\begin{array}{l}\text { ALPHA - } \\
\text { central } \\
\text { multisourcing } \\
\text { team }\end{array}$ & $\begin{array}{l}\text { Transition } \\
\text { manager }\end{array}$ \\
\hline v_1 & I & $\begin{array}{l}\text { ALPHA - } \\
\text { central } \\
\text { multisourcing } \\
\text { team }\end{array}$ & $\begin{array}{l}\text { Project } \\
\text { manager }\end{array}$ \\
\hline v_2 & II & $\begin{array}{l}\text { Business } \\
\text { entity of } \\
\text { ALPHA }\end{array}$ & $\begin{array}{l}\text { Multisourcing } \\
\text { manager }\end{array}$ \\
\hline v_3 & III & $\begin{array}{l}\text { Offshore } \\
\text { centre of } \\
\text { ALPHA }\end{array}$ & $\begin{array}{l}\text { Relationship } \\
\text { manager }\end{array}$ \\
\hline v_3 & III & $\begin{array}{l}\text { Strategic } \\
\text { external } \\
\text { vendor }\end{array}$ & $\begin{array}{l}\text { Relationship } \\
\text { manager }\end{array}$ \\
\hline
\end{tabular}

\section{Company ALPHA's journey towards multisourcing}

In the following the authors describe the general setup at company ALPHA, the development of a 
multisourcing strategy and the specific requirements of company ALPHA that are derived from the implementation of the multisourcing concept.

\subsection{General setup}

Company ALPHA is one of the leading financial services providers worldwide. It serves more than 75 million clients with about 150,000 employees and offers insurance, banking, and asset management products in about 70 countries. Company ALPHA is a multinational enterprise with a group center and more than 100 business entities. It can be described best as a management holding with a group center and legally independent business entities where the group center does not assume any operational responsibility and rather manages the group. A management holding can be specified by a systematic delegation of duties between the group center and the business entities. It combines e.g. the advantages of smaller, local companies like flexibility and customer orientation with those of large enterprises like market presence and power as well as economies of scale $[21,25]$.

In the IT function, company ALPHA can be characterized through a more decentralized organization with both a Group Chief Information Officer (Group CIO) and local CIOs at business entity level and a federal model in regards of IT governance. Weill and Ross define the federal model "as coordinated decision making involving both a center and its business units" $[29,30]$ and Handy emphasizes that responsibilities and accountabilities of multiple governing bodies span at least two hierarchical tiers [11]. This is e.g. reflected in an IT committee that is headed by the Group CIO and encompasses local CIOs of the main business entities.

\subsection{Development and implementation of a multisourcing strategy}

Up to two years ago company ALPHA had neither a coherent, group-wide sourcing strategy in the IT function nor a high degree of offshoring. The supplier base was largely unconsolidated and the costs were not competitive with best-in-class market players. Company ALPHA therefore developed a global sourcing strategy in order to achieve three objectives. First, reduce factor costs; second, increase service quality; and third, reduce complexity in the application landscape. These aims were to be achieved by leveraging company ALPHA's own offshore center, and by consolidating the remaining sourcing activities to a few strategic external vendors.

The multisourcing concept at company ALPHA has been developed by a central multisourcing team at the group center and rolled-out in different waves to the business entities. The business entities' CIOs were responsible for implementing the multisourcing concept at business entity level. The central multisourcing team supported the local CIOs but did not have the authority to force them to implement the multisourcing concept due to low central governance.

The centrally developed concept encompassed a contractual framework with a few strategic external service vendors. The contractual framework comprises of:

- The multisourcing master service agreement (MMSA) at group level

- The multisourcing business entity specific service agreement $(M B S A)$ at business entity level

- The multisourcing project specific service agreement (MPSA) at project level

Figure 1 illustrates the contractual framework with its components on three levels and the involved parties. The MMSA is a comprehensive legal framework covering the global relationship between company ALPHA as a group and each of the strategic external vendors (group level). Each individual business entity has to sign a $M B S A$ with the respective local subsidiary of the strategic external vendors. This aims to cover local laws and regulations (e.g., country specific laws) at a business entity level. For each project a MPSA has to be signed between the business entity and the respective subsidiary of the strategic external vendor. The MPSA is strictly project related and does not cover legal topics anymore.

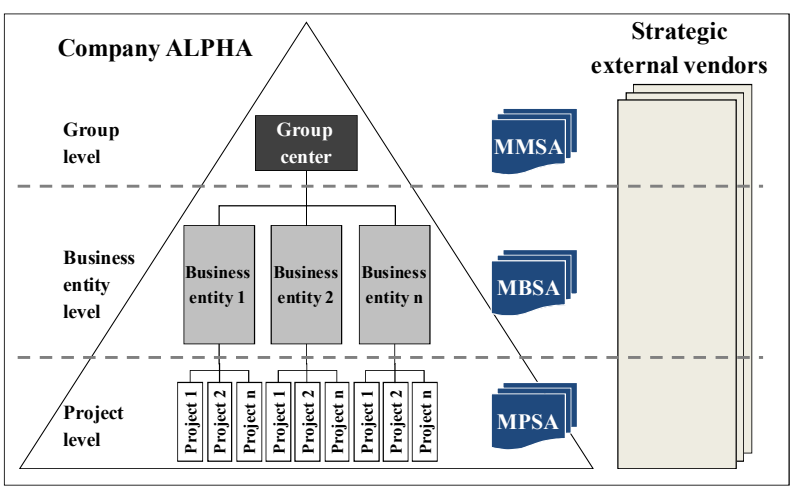

Figure I: Contractual framework

\subsection{Requirements of company ALPHA}

The main challenge company ALPHA faced was the implementation of the concept at the more than 100 business entities whilst not having central governance to force business entities. Consequently the need for an IT governance instrument has been identified that 
enables the monitoring of the implementation progress and provides best-practices for implementing and executing the multisourcing concept at business entity level. Therefore the following requirements have been defined:

- $\quad$ [R.1] Provide transparency along the multisourcing life-cycle

- $\quad$ [R.2] Enable the monitoring of the implementation progress at business entities

- $\quad$ [R.3] Allow for comparison and classification of different business entities

- $\quad$ [R.4.1] Provide best-practices to improve the implementation process at business entities

- $\quad$ [R.4.2] Provide best-practices to optimize the execution of multisourcing at business entities

- $\quad$ [R.5] Avoid ambiguities

- [R.6] Provide a coherent approach

- $\quad$ [R.7] Maintain ease of execution

To meet the requirements in general and the requirements R.2, R.3, R.4.1 and R.4.2 in particular, the central multisourcing team decided to apply the concept of a maturity model because maturity models are conceptual models that outline an anticipated, typical, logical, and desired evolution path [5]. According to Becker et al. "advancing on this path involves a continuous progression regarding the organization's capabilities or process performance" [4]. Thereby a maturity model provides criteria and characteristics that need to be fulfilled to reach a particular maturity level [4]. Maturity models are used to assess the as-is situation, to derive and prioritize improvement measures and to control implementation progress [16]. Those characteristics support the need of company ALPHA.

\section{Analysis of existing best-practices}

In a first step the maturity model core team at company ALPHA decided to analyze existing bestpractices and to validate if these concepts could be applied as whole or partially to the requirements identified earlier in this article. This analysis aims to answer research question 1 ([RQ.1] Are existing bestpractices and especially established maturity models applicable to a multisourcing specific situation at a multinational enterprise with a federal IT organization?)

First a literature review was conducted in order to identify relevant best-practices. In a second step, the relevant concepts were analyzed in terms of their fit regarding the requirements of company ALPHA.

Within the literature review the authors searched for maturity models that correspond to the sourcing situation of company ALPHA, are already established across multinational enterprises and well documented. The following maturity models have been identified:

- Capability Maturity Model Integration for Acquisition (CMMI-ACQ) [26]

- $\quad$ SSourcing Capability Model for Client Organizations (eSCM-CL) [15]

- $\quad$ IT Procurement Maturity Model [6]

In addition to the maturity models, best-practice frameworks of market research companies such as Gartner, Inc. and Forrester Research, Inc. were analyzed; their experience with multisourcing means they are of considerable practical relevance for company ALPHA. The following two concepts have been identified:

- $\quad$ Gartner Multisourcing Competencies [24]

- Forrester Multisourcing Roadmap [9]

Subsequently, all concepts have been analyzed and evaluated in terms of the requirements of company ALPHA. The detailed analysis can be seen in Table 2 (full means completely accomplished, half means somewhat accomplished, and empty means not accomplished).

It can be observed that the two established frameworks CMMI-ACQ and $e S C M-C L$ are far too detailed and that requirement R.7 (ease of execution) is not met at all. Furthermore, the maturity models provide, of course, best-practices but do not meet the multisourcing specific requirements in terms of providing best-practices to the business entities either in order to improve the implementation process (R.4.1) or to optimize the execution of the multisourcing concept (R.4.2). Additionally, the important requirements in terms of providing transparency along the multisourcing life-cycle (R.1) and monitoring the implementation progress (R.2) are not addressed.

Nevertheless, CMMI-ACQ, eSCM-CL, and to some extent the Gartner IT Procurement Maturity Model provide an established methodological basis and some content-wise aspects for the development of a company ALPHA specific multisourcing framework. They allow company ALPHA to compare and classify business entities (R.3), avoid ambiguities (R.5) and provide a coherent approach (R.6). Therefore company ALPHA applies the proven maturity methodology of CMMI$A C Q$, eSCM-CL, and Gartner with various maturity levels and predefined best-practices.

The identified best-practice frameworks of market researchers are simply a list of competencies and bestpractices to be taken into account. They do not allow for comparison or classification (R.3), may lead to ambiguities (R.5) and do not provide a coherent approach (R.6). 
Table 2: Analysis of existing maturity models / best-practice frameworks

\begin{tabular}{|c|c|c|c|c|c|}
\hline $\begin{array}{c}\text { Requirements of company } \\
\text { ALPHA }\end{array}$ & $\begin{array}{l}\text { CMMI- } \\
\text { ACQ } \\
{[26]}\end{array}$ & $\begin{array}{l}\text { eSCM- } \\
\text { CL } \\
{[15]}\end{array}$ & $\begin{array}{c}\text { IT } \\
\text { Procurement } \\
\text { Maturity } \\
\text { Model } \\
\text { [6] }\end{array}$ & $\begin{array}{c}\text { Gartner } \\
\text { Multi- } \\
\text { sourcing } \\
\text { Competencies } \\
{[24]}\end{array}$ & $\begin{array}{c}\text { Forrester } \\
\text { Multi- } \\
\text { sourcing } \\
\text { Roadmap } \\
\text { [9] }\end{array}$ \\
\hline $\begin{array}{l}\text { [R.1] Transparency along the } \\
\text { multisourcing life-cycle }\end{array}$ & & & & & \\
\hline $\begin{array}{l}\text { [R.2] Monitoring of } \\
\text { implementation progress at } \\
\text { business entities }\end{array}$ & & & & & \\
\hline $\begin{array}{l}\text { [R.3] Comparison and } \\
\text { classification of business entities }\end{array}$ & & & & & \\
\hline $\begin{array}{l}\text { [R.4.1] Provide best-practices to } \\
\text { improve implementation process } \\
\text { at business entities }\end{array}$ & & & & & \\
\hline $\begin{array}{l}\text { [R.4.2] Provide best-practices to } \\
\text { optimize execution of } \\
\text { multisourcing at business entitie }\end{array}$ & & & & & \\
\hline [R.5] Ambiguity avoidance & & & & & \\
\hline [R.6] Coherent approach & & & & & \\
\hline [R.7] Ease of execution & & & & & \\
\hline
\end{tabular}

However, those approaches are easy to implement (R.7) and do provide a good overview of competencies a company should acquire while applying a multisourcing concept (R.4.1, R.4.2). In addition, transparency along the multisourcing life-cycle (R.1) and the ability to monitor the implementation progress are given to some extent. Therefore especially contentoriented aspects were taken into account at company ALPHA.

\section{Towards a multisourcing maturity model}

Since none of the analyzed best-practice frameworks could be applied to the identified requirements an own multisourcing maturity model has been developed. This concept adopts established elements of the analyzed frameworks and complements it with the detailed requirements. In the following the authors describe first the approach of company ALPHA and second some exemplary details of the different maturity levels. With this the authors target research question 2 ([RQ.2] What could a multisourcing specific maturity model targeting the challenges of a multinational enterprise with a federal IT organization look like?).

\subsection{The concept of the multisourcing maturity model}

The multisourcing maturity model is based on the methodology of established maturity models such as $C M M I-A C Q, \quad e S C M-C L$, and the Gartner IT Procurement Maturity Model and integrates bestpractices derived both from the maturity models as well as the market researchers.

Table 3 gives an overview of the maturity model that has been developed. Horizontally it separates five maturity levels and vertically it represents the multisourcing life-cycle. 
Table 3: Multisourcing maturity model

\begin{tabular}{|c|c|c|c|c|c|c|}
\hline $\begin{array}{l}\text { Dimen- } \\
\text { sion }\end{array}$ & $\begin{array}{c}\text { Sub- } \\
\text { Dimension }\end{array}$ & Level 1 & Level 2 & Level 3 & Level 4 & Level 5 \\
\hline \multirow{2}{*}{ 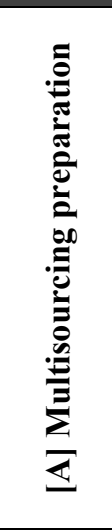 } & $\begin{array}{c}\text { [A.1.] } \\
\text { Utilization of } \\
\text { contractual } \\
\text { multisourcing } \\
\text { framework }\end{array}$ & $\begin{array}{c}\text { [A.1.1] } \\
\text { MBSA with } \\
\text { vendors have } \\
\text { not been } \\
\text { signed }\end{array}$ & $\begin{array}{c}\text { [A.1.2] } \\
\text { MBSA with } \\
\text { vendors have } \\
\text { been piloted }\end{array}$ & $\begin{array}{l}\text { [A.1.3] } \\
\text { MBSA with } \\
\text { vendors and } \\
\text { at least one } \\
\text { MPSA have } \\
\text { been signed } \\
\end{array}$ & $\begin{array}{c}\text { [A.1.4] } \\
\text { MMSA, } \\
\text { MBSA, and } \\
\text { MPSA are } \\
\text { widely used }\end{array}$ & $\begin{array}{c}\text { [A.1.5] } \\
\text { MMSA, } \\
\text { MBSA, and } \\
\text { MPSA are } \\
\text { established for } \\
\text { all projects } \\
\end{array}$ \\
\hline & $\begin{array}{c}\text { [A.2] } \\
\text { Aspiration } \\
\text { level of } \\
\text { applying } \\
\text { multisourcing }\end{array}$ & $\begin{array}{c}\text { [A.2.1] } \\
\text { Financial } \\
\text { benefits of } \\
\text { applying } \\
\text { multisourcing } \\
\text { have not been } \\
\text { estimated }\end{array}$ & $\begin{array}{c}\text { [A.2.2] } \\
\text { Financial } \\
\text { benefits of } \\
\text { applying } \\
\text { multisourcing } \\
\text { have been } \\
\text { estimated }\end{array}$ & $\begin{array}{c}\text { [A.2.3] } \\
\text { Financial } \\
\text { benefits have } \\
\text { been } \\
\text { committed }\end{array}$ & $\begin{array}{l}\text { [A.2.4] } \\
\text { Besides } \\
{[A .2 .3], \text { the }} \\
\text { productivity } \\
\text { has been } \\
\text { increased }\end{array}$ & $\begin{array}{c}\text { [A.2.5] } \\
\text { In addition to } \\
{[A .2 .4], \text { the }} \\
\text { complexity } \\
\text { has been } \\
\text { decreased }\end{array}$ \\
\hline \multirow{2}{*}{ 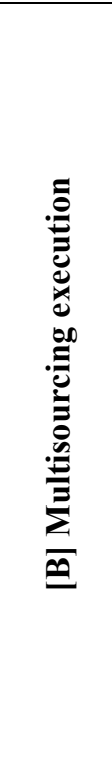 } & $\begin{array}{c}\text { [B.1] } \\
\text { Adaptation of } \\
\text { roles and } \\
\text { responsibilities } \\
\text { (R\&R) }\end{array}$ & $\begin{array}{c}\text { [B.1.1] } \\
\text { Specific } \\
\text { multisourcing } \\
\text { R\&R are not } \\
\text { existing }\end{array}$ & $\begin{array}{c}\text { [B.1.2] } \\
\text { A few } \\
\text { multisourcing } \\
\text { specific R\&R } \\
\text { have been } \\
\text { identified and } \\
\text { some have } \\
\text { been } \\
\text { established }\end{array}$ & $\begin{array}{c}\text { [B.1.3] } \\
\text { The most } \\
\text { important } \\
\text { multisourcing } \\
\text { R\&R have } \\
\text { been } \\
\text { established }\end{array}$ & $\begin{array}{c}\text { [B.1.4] } \\
\text { All specific } \\
\text { multisourcing } \\
\text { R\&R have } \\
\text { been } \\
\text { established }\end{array}$ & $\begin{array}{c}\text { [B.1.5] } \\
\text { Continuous } \\
\text { improvement / } \\
\text { optimization } \\
\text { of } \\
\text { multisourcing } \\
\text { specific R\&R }\end{array}$ \\
\hline & $\begin{array}{c}{[\mathrm{B} .2]} \\
\text { Establishment } \\
\text { of } \\
\text { multisourcing } \\
\text { processes }\end{array}$ & $\begin{array}{c}{[\mathrm{B} .2 .1]} \\
\text { Multisourcing } \\
\text { processes are } \\
\text { not } \\
\text { established }\end{array}$ & $\begin{array}{c}\text { [B.2.2] } \\
\text { Multisourcing } \\
\text { processes } \\
\text { have been } \\
\text { piloted }\end{array}$ & $\begin{array}{c}\text { [B.2.3] } \\
\text { Multisourcing } \\
\text { processes } \\
\text { have been } \\
\text { established } \\
\text { for the } \\
\text { majority of } \\
\text { relevant } \\
\text { sourcing } \\
\text { projects } \\
\end{array}$ & $\begin{array}{c}{[\text { B.2.4] }} \\
\text { Multisourcing } \\
\text { processes have } \\
\text { been } \\
\text { established for } \\
\text { all relevant } \\
\text { sourcing } \\
\text { projects }\end{array}$ & $\begin{array}{c}\text { [B.2.5] } \\
\text { Continuous } \\
\text { improvement / } \\
\text { optimization } \\
\text { of } \\
\text { multisourcing } \\
\text { processes }\end{array}$ \\
\hline \multirow{2}{*}{ 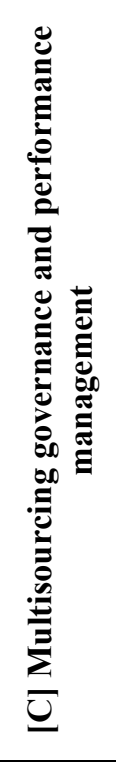 } & $\begin{array}{c}\text { [C.1] } \\
\text { Utilization of } \\
\text { multisourcing } \\
\text { governance } \\
\text { principles }\end{array}$ & $\begin{array}{c}{[\text { C.1.1] }} \\
\text { Multisourcing } \\
\text { governance } \\
\text { principles are } \\
\text { not } \\
\text { established }\end{array}$ & $\begin{array}{l}\text { [C.1.2] } \\
\text { Multisourcing } \\
\text { governance } \\
\text { principles are } \\
\text { limited to } \\
\text { purchasing }\end{array}$ & $\begin{array}{c}\text { [C.1.3] } \\
\text { Multisourcing } \\
\text { governance } \\
\text { principles are } \\
\text { actively } \\
\text { piloted } \\
\text { beyond } \\
\text { purchasing }\end{array}$ & $\begin{array}{c}\text { [C.1.4] } \\
\text { Multisourcing } \\
\text { governance } \\
\text { principles have } \\
\text { been } \\
\text { established } \\
\text { across the } \\
\text { business entity }\end{array}$ & $\begin{array}{c}\text { [C.1.5] } \\
\text { Continuous } \\
\text { improvement / } \\
\text { optimization } \\
\text { of } \\
\text { Multisourcing } \\
\text { governance } \\
\text { principles }\end{array}$ \\
\hline & $\begin{array}{c}\text { [C.2] } \\
\text { Usage of } \\
\text { multisourcing } \\
\text { KPIs }\end{array}$ & $\begin{array}{c}{[\text { C.2.1] }} \\
\text { Multisourcing } \\
\text { KPIs are not } \\
\text { established }\end{array}$ & $\begin{array}{c}\text { [C.2.2] } \\
\text { A few } \\
\text { multisourcing } \\
\text { KPIs have } \\
\text { been } \\
\text { established }\end{array}$ & $\begin{array}{c}\text { [C.2.3] } \\
\text { A group } \\
\text { standard set } \\
\text { of financial } \\
\text { and } \\
\text { operational } \\
\text { multisourcing } \\
\text { KPIs have } \\
\text { been } \\
\text { identified and } \\
\text { established } \\
\end{array}$ & $\begin{array}{c}\text { [C.2.4] } \\
\text { In addition to } \\
{[\text { C.2.3], }} \\
\text { supplier } \\
\text { performance } \\
\text { KPIs have } \\
\text { been identified } \\
\text { and established }\end{array}$ & $\begin{array}{c}{[\text { C.2.5] }} \\
\text { An integrated } \\
\text { dashboard of } \\
\text { multisourcing } \\
\text { KPIs and } \\
\text { business KPIs } \\
\text { has been } \\
\text { identified and } \\
\text { established }\end{array}$ \\
\hline
\end{tabular}


Following CMMI-ACQ, eSCM-CL, and the Gartner IT Procurement Maturity Model, company ALPHA applied five maturity levels $[26,15,6]$. The following maturity levels have been defined in order to classify company ALPHA's business entities' maturity towards multisourcing and allow for comparison (R.3):

- Level 1: Multisourcing prepared

- Level 2: Multisourcing engaged

- Level 3: Multisourcing established

- Level 4: Multisourcing managed

- Level 5: Multisourcing optimized

In addition to the five above mentioned maturity levels, a level 0 labeled multisourcing incomplete has also been defined. Level 0 applies to business entities that do not deal with multisourcing at all.

In order to move from level 0 to level 1 (multisourcing prepared) the business entities need to fulfill the following basic multisourcing requirements that are not included in Table 3:

- Awareness about the multisourcing concept and its contractual framework

- Identification of business entity specific multisourcing potentials

- Integration of the multisourcing concept into business entities' sourcing strategy

This provides the ability to monitor the implementation progress at business entity level (R.2).

Besides the maturity levels company ALPHA defined three dimensions that are related to the lifecycle of their business entities' multisourcing endeavors and are derived both from practitioner literature (see inter alia $[9,24]$ ) as well as scholarly literature (see inter alia [1]). Each dimension is subdivided into two sub-dimensions providing coherent transparency (R.1).

While integrating the above mentioned concepts from a content perspective and accumulating with the experience of the central multisourcing team as well as representatives from external vendors, from the company's own offshore center and business entities' representatives, a multisourcing specific best-practice framework was defined during a number of cycles (R.4.1, R.4.2). By concentrating on three dimensions the model provides a coherent approach whilst maintaining ease of execution (R.6, R.7). In addition, it is supported by clear definitions for all applied terms (R.5) by an extensive documentation.

\subsection{Exemplary description of the multisourcing maturity levels}

The multisourcing maturity model has two extremes: the lower end level 1 labeled multisourcing prepared and the upper end level 5 labeled multisourcing optimized. It is beyond the scope of this article to describe all multisourcing maturity levels in detail and therefore the authors will focus exclusively on the two extremes.

5.2.1. Level 1: Multisourcing prepared. At the lower extreme of the multisourcing maturity model level 1: multisourcing prepared - a business entity is required to fulfill the above mentioned basic multisourcing requirements (see 5.1) indicating that the multisourcing concept is part of the business entities' sourcing strategy, that the business entity specific potentials have been identified and that the business entity is aware of the contractual framework negotiated by the group center. Thereby it is distinguished from level 0 (multisourcing incomplete). Level 1 proves that the business entity would be "prepared" to use the multisourcing concept but does not require any deliverables from the business entity so far. Therefore, for instance, the multisourcing business entity specific agreements (MBSA) with the external vendors do not need to be signed (A.1.1) or multisourcing specific roles and responsibilities do not exist (B.1.1). As of level 2, defined deliverables need to be accomplished in order to progress to another maturity level.

5.2.2. Level 5: Multisourcing optimized. At the upper extreme of the multisourcing maturity model a business entity is classified as multisourcing optimized (level 5). A business entity has established the whole contractual framework - encompassing the multisourcing master service agreement (MMSA), the multisourcing business entity specific agreement (MBSA), and the multisourcing project specific agreement (MPSA) - for all relevant projects across the whole organization (A.1.5). It has achieved all three defined objectives of company ALPHA's multisourcing strategy, namely cost reduction, productivity enhancement and complexity reduction (A.2.5). It continuously improves and optimizes multisourcing specific roles and responsibilities (B.1.5), multisourcing processes (B.2.5), and multisourcing governance principles (C.1.5). Furthermore the business entity is required to establish an integrated dashboard of multisourcing KPIs - encompassing a group standard set of financial KPIs, operational KPIs, and supplier 
performance KPIs - and business entity specific business KPIs (C.2.5).

\section{Lessons learned}

During the collaborative study with company ALPHA, the authors found a set of lessons learned. The most relevant ones are described in the following chapter.

Lesson 1: Besides providing transparency and enabling the monitoring of the implementation progress, the concept of maturity models provides best-practices to the business entities of company ALPHA. Company ALPHA's low central governance required an instrument that provides transparency and enables the monitoring of the implementation progress of the multisourcing concept at the numerous business entities. This can be achieved by classifying each business entity applying the maturity level descriptions. In addition, the maturity level descriptions provide a set of best-practices to the business entities in order to improve the implementation process and optimize the multisourcing execution.

Lesson 2: Adaption of established maturity models required to meet specific needs. While working jointly with company ALPHA, the researchers determined that established maturity models do not match company ALPHAs' specific requirements. However, proven methodologies such as the maturity level concept should be applied.

Lesson 3: Low central governance complicates the implementation process of a centrally developed multisourcing concept. In the case of company ALPHA, it can be noticed that the low central governance within the federal IT organization complicated the implementation process at business entity level. The central multisourcing team had to provide a great deal of support and persuasion while communicating on a constant basis with the responsible business entity CIOs. The need for additional IT governance instruments has been identified.

Lesson 4: Integration of all relevant stakeholders fosters acceptance of the maturity model. The integration of all relevant stakeholders fosters the acceptance of the maturity model and ensures high quality. Especially in an organization with a federal model it is recommended to involve and inform all stakeholders from the beginning.

Lesson 5: Extensive documentation of the concept and lessons learned facilitates successful implementation. The basis for a successful implementation of the maturity model is an extensive documentation of the concepts, the applied terms and the lessons learned. Furthermore ambiguities can be avoided. A detailed documentation provides bestpractices to the business entities and illustrates an evolution path in order to improve the implementation process and optimize the execution of a multisourcing strategy.

\section{Conclusion and further research}

With this article the authors describe a multisourcing specific maturity model that has been developed at company ALPHA and used as an IT governance instrument in a federal IT organization. In order to contribute both to the practical concerns of company ALPHA and the scientific body of knowledge an action research based approach was chosen.

The authors target two research questions. First they analyze and evaluate established maturity models in terms of the specific requirements of company ALPHA in order to address research question 1 ([RQ.1] Are existing best-practices and especially established maturity models applicable to a multisourcing specific situation at a multinational enterprise with a federal IT organization?). Consequently, established maturity models such as CMMI-ACQ, eSCM-CL, and the Gartner IT Procurement Maturity Model have been analyzed and evaluated in terms of company ALPHAs' specific requirements. It has been figured out that none of the existing maturity models can be applied to the specific multisourcing situation at company ALPHA. Notwithstanding, the methodology and some contentoriented aspects should be adapted.

Second, based upon those observations the authors describe a maturity model that has been developed at company ALPHA in order to meet company ALPHA's specific requirements within a federal IT organization. Herewith, the authors target research question 2 ([RQ.2] What could a multisourcing specific maturity model targeting the challenges of a multinational enterprise with a federal IT organization look like?). Company ALPHA's multisourcing maturity model is based on the methodology of established maturity models and separates five maturity levels. The three main dimensions of the model are derived from the multisourcing life-cycle described both in practitioner as well as scholarly literature. Each maturity level is described by a precise set of characteristics that allow company ALPHA to monitor the implementation progress at business entity level.

With this study the authors provide insights into a real-life example of developing and implementing a multisourcing strategy at one of the leading financial 
service providers worldwide and describe an IT governance instrument that enables company ALPHA to provide group-wide transparency, facilitate continuous monitoring of the implementation progress and allow the provisioning of best-practices to all business entities.

This article is, however, beset with certain limitations, for instance, the very close project setup with company ALPHA. Or, that a different selection of maturity models and best-practices of market research companies would have led to a slightly diverse outcome.

However, this article describes only an initial study which is expected to lead to considerable practical and theoretical work in the future. The authors expect to conduct further studies on how multinational enterprises govern the implementation of multisourcing concepts. Especially in regards of the applicability of the derived maturity model the authors suggest further research. On the one hand detailed effects of the implementation of the maturity model as well as the success of the multisourcing concept at company ALPHA should be further investigated. On the other hand the maturity model of company ALPHA could be applied to another company and it might be worthwhile to investigate the approaches of comparable companies facing a similar situation.

\section{References}

[1] S. Alborz, P. Seddon and R. Scheepers, "A Model for Studying IT Outsourcing Relationships", Proceedings of the 7th Pacific Asia Conference on Information Systems (PACIS), 2003.

[2] R. L. Baskerville, "Investigating information systems with action research", Communications of AIS, 2, 1999.

[3] R. L. Baskerville and A. T. Wood-Harper, "A critical perspective on action research as a method for information systems research", Journal of Information Technology, 11, 1996, pp. 235-246.

[4] J. Becker, R. Knackstedt and J. Pöppelbuß, "Developing Maturity Models for IT Management", Business \& Information Systems Engineering, 1, 2009, pp. 213-222.

[5] J. Becker, B. Niehaves, J. Pöppelbuß and A. Simons, "Maturity Models in IS Research", Proceedings of the 18th European Conference on Information Systems (ECIS), 2010.

[6] S. Buchanan, Gartner Maturity Model for IT Procurement, Gartner Research, Inc., Stamford, CT, 2007.

[7] P. Checkland and S. Holwell, "Action Research: Its Nature and Validity", Systemic Practice and Action Research, 11, 1998, pp. 9-21.

[8] L. R. Cohen and A. Young, Multisourcing: Moving Beyond Outsourcing to Achive Growth and Ability, Harvard Business School Press, Bosten, MA, 2006.

[9] E. Davis, The 10 Steps To Multisourcing Successfully, Forrester Research, Inc., Cambridge, MA, 2010.
[10] R. M. Davison, M. G. Martinsons and N. Kock, "Principles of canonical action research", Information Systems Journal, 14, 2004, pp. 65-86.

[11] C. Handy, "Balancing corporate power: A new federalist paper", Harvard Business Review, 70, 1992, pp. 59-72.

[12] T. P. Herz, F. Hamel, F. Uebernickel and W. Brenner, "Deriving a Research Agenda for the Management of Multisourcing Relationships Based on a Literature Review", Proceedings of the Sixteenth Americas Conference on Information Systems (AMCIS), 2010.

[13] B. Huber, Agile Multi-Sourcing: A Critical Business Trend - Concepts and Background, Technology Partners International, Inc., Housten, TX, 2008.

[14] M. Hult and S.-A. Lennung, "Towards a Definition of Action Research: A Note and Bibliography", Journal of Management Studies, 17, 1980, pp. 241-250.

[15] ITSqc, The eSourcing Capability Model for Client Organizations (eSCM-CL), IT Sourcing Certification Group, Carnegie Mellon University, Pittsburgh, PA, 2006.

[16] J. Iversen, P. A. Nielsen and J. Nerbjerg, "Situated Assessment of Problems in Software Development", The DATA BASE for Advances in Information Systems, 30, 1999, pp. 66-81.

[17] B. Janischowsky and R. Schonenbach, Getting Multisourcing Right!, CEO Today 2009, Sovereign Publications, London, 2009.

[18] N. Levina and N. Su, "Global Multisourcing Strategy: The Emergence of a Supplier Portfolio in Services Offshoring", Decision Sciences, 39, 2008, pp. 541-570.

[19] K. Lewin, Field Theory in Social Science, Harper \& Bros, New York, 1951.

[20] M. Mayo, T. Lang and D. Aitchison, The TPI Index An Informed View of the State of the Global Commercial Outsourcing Market - Fourth Quarter and Full-year of 2009, Technology Partnes International, Inc., Houstan, TX, 2010.

[21] G. Obermeier, Shareholder Value-Oriented Management in the Light of Gutenberg's Theories, in $\mathrm{H}$. Albach, K. Brockhoff, E. Eymann, P. Jungen, M. Steven and A. Luhner, eds., Theory of the Firm: Erich Gutenberg's Foundations and Further Developments, Springer, Berlin, 2000, pp. 104-117.

[22] I. Oshri, J. Kotlarsky, J. W. Rottman and L. L. Willcocks, "Global sourcing: recent trends and issues", Information Technology \& People, 22, 2009, pp. 192-200.

[23] R. N. Rapoport, "Three dilemmas of action research", Human Relations, 23, 1970, pp. 499-513.

[24] F. Ridder and L. R. Cohen, Ten Competencies and Key Activities for Mastering Multisourcing, Gartner Research, Inc., Stamford, CT, 2008.

[25] M. Schulte-Zurhausen, Organisation, Vahlen, München, 2004.

[26] SEI, CMMI for Acquisition, Version 1.2, Software Engineering Institute, Carnegie Mellon University, Pittsburgh, PA, 2007.

[27] G. I. Susman and R. D. Evered, "An Assessment of the Scientific Merits of Action Research", Administrative Science Quarterly, 23, 1978, pp. 582-603.

[28] D. Tapper, Worldwide and U.S. IS Outsourcing Services 2009-2013 Forecast Update: November 2009, 
International Data Corporation (IDC), Framingham, MA, 2009.

[29] P. Weill, "Don't Just Lead, Govern: How TopPerforming Firms Govern IT", MIS Quarterly Executive, 8, 2004, pp. 1-21.

[30] P. Weill and J. W. Ross, IT Governance: How top performers manage IT decision rights for superior results, Harvard Business Press, Boston, MA, 2004. 